ISBN / 978-93-5137-179-3

ISSN

$2320-7329$

Ayurlog: National Journal of Reseach in Ayurved Science

\title{
Prevention of suicidal attempts in present era through ayurveda and yoga.
}

\author{
Patil Rajendra Vinayak, ${ }^{1} *$ Kathane Vikas Charandas, ${ }^{2}$ Patrikar Vijay Gangadhar ${ }^{3}$
}

1. Assistant Professor,

2. Associate Professor, Department of Swasthavritta and Yoga,

Bhaisaheb Sawant Ayurved Mahavidyalaya and Hospital,Sawantwadi, Maharashtra, India.

3. Professor, Department of Swasthavritta and Yoga, Government Ayurved College Nagpur, Maharashtra, India.

*Corresponding Author: dr.rvpatil@ rediffmail.com; .08484907236

\section{Abstract:}

The phenomena of suicide and suicidal behavior are public health concerns globally, across developed and developing countries. Every year, more than one million people die by suicide and there are many more people who attempt suicide globally. It is a public health issue that affects communities, provinces and entire countries. Ange of suicidal attempt dramatically affects the lives of families, friends and entire communties. In today's scenario of India the incidence rate of suicidal attempts increased day by day despite all the odds. Majority of vulnerable populations for suicide includes farmers, students, women, armeet forces, migrant populations, those with chronic physical and mental illness. The act of suicide consisting hanging, poisoning, train run-over, drowning, alcohol abuse, burn etc. and cause behind suicide was excessive stress, economical conditions, depression, disturbed interpersonal relationships and internet games like Blue Whale Challenge. A detailed analysis of reasons of increasing incidences of suicides has been done in this present study. Suicide is not only a crime but it is a serious health problem which is easily preventable by adopting principles of ayurveda and yoga. There is a close and scientifically proved relation between suicide and psychosomatic disorders particularly in stress, depression and alcohol abuse. Different regimen of ayurveda and yoga has been adopted to cope with the stress, anxiety, the root cause of suicide. This regimen includes sadvrutta (code and conducts of life), Satvavajay(spiritual therapy) and daivyavyapashray chikitsa(divine therapy) along with yama (ethical rules), niyam(principles for social well being), asan(yoga posture), pranayama (breathing techniques), pratyahara(control of sense organs), and dhyan (mediatation). Hence to prevent this smoldering problem of suicide the 'Sciences of life' i.e. ayurveda and Yoga offers the lifestyle modifying, time effective, free of cost, objective therapy (Adravyabhoot chikita) through it's basic principles. A detailed review of ayurvedic and yogic regimen to prevent suicides by removing depression has been done in this study.

KEYWORD: Suicide, Ayurveda, Yoga, Stress, Prevention, Blue Whale challenge, Satvavajay, dhyan 


\section{INTRODUTION}

Suicide is a global phenomenon in all regions of the world; in fact $78 \%$ of global suicide occurred in low-and middle income countries ${ }^{[1]}$. Suicide accounted for $1.4 \%$ of all deaths worldwide, making in $17^{\text {th }}$ cause of death ${ }^{[2]}$. Every year, more than one million people die by suicide and there are many more people who attempt suicide globally. Each suicide is a personal tragedy that prematurely takes the life of an individual and has a continuing ripple effect, dramatically affecting the lives of families, friends, communities and entire countries. Every year, more than one million people die by suicide-one person every 40 seconds. Young people are among those most affected; suicide is now the second leading cause of death for those between the ages of 15 and 29 years globally. ${ }^{[3]}$ In May 2013, the Sixty-sixt World Health Assembly formally adopte the first-ever Mental Health Action Plan of the World Health Organization (WHO). The action plan calls on all WHO Member States to demonstrate their increased commitment to mental health by achieving specific targets. Suicide prevention is an integral component of the Mental Health Action Plan, with the goal of reducing the rate of suicide in countries by 10 by 2020 . $^{\text {[4] }}$

In year 2015, the global burden of suicide in SEAR(South East Asia Region) countries was 12.9 per 100000 population, which is the second place among all continents. $^{[5]}$ At that time India estimates the suicide mortality rate 15.7 per 100000 population. ${ }^{[6]}$ Now a days, In India there is tremendous increase in suicidal attempts in farmers particularly in rural areas, due to cyclic weather events such as significant drought and floods. As of 2017, farmer suicides have occurred in large numbers in Maharashtra, Andhra Pradesh, Telengana, Tamil Nadu, Madhya Pradesh, Bihar, Uttar Pradesh, Chhattisgarh, Orissa and Jharkhand. ${ }^{[7]}$ This climate variability together with lower socio-economic conditions and reduced farm production has combined to produce insidious impacts on the health resulting into depression. Such depressed person most vulnerable to suicidal attempt. National Crime Records Bureau, an office of the Ministry of Home Affairs Government of India, has been collecting and publishing suicide statistics for India since the 1950s, as annual Accidental Deaths and Suicides in India reports. It started separately collecting and publishing farmer's suicide statistics from 1995. ${ }^{[8]} \mathrm{A}$ multipronged approach including financial, material, and sychological support is needed to reduce he incidence of suicide among the farmers who are the back bone of our country.

On the other hand youth in India plays a Blue Whale Challenge", is an Internet "game" which is linked to suicide. The game allegedly consists of a series of tasks assigned to players by administrators during a 50-day period, with the final challenge requiring the player to commit suicide. ${ }^{[9,10]}$ This emerging phenomenon of "cyber suicide" in the internet era is a further cause for concern. ${ }^{[11,12]}$ In India most of the suicide and suicidal attempts consisting poisoning, hanging, train run-over, drowning, alcohol abuse, burn etc. and cause behind suicide was excessive stress, economical conditions, depression, disturbed interpersonal relationships. There is a close and scientifically proved relation between suicide and depression. It is well acknowledged that depression influences the occurrence and outcomes of several diseases and conditions. Depression and suicide are closely interlinked; at its worst, depression can 
lead to suicide. Globally, depression is the top cause of illness and disability among young and middle-aged populations, while suicide ranks second among causes of death for the same age groups. ${ }^{[13]}$ In majority of cases victims suffer from a long lasting stress caused either by individual or social reasons. Individual reasons such as financial problems, relationship problems or health related events cause immense stress. Sometimes social problems like some social stigmas, dowry, social boycotts etc. leads to suicidal attempts. In all the main cause behind suicides is depression caused by either individual or social reasons. Hence to counteract this condition World Health Organization launch and implemented the theme "Depression-Let's talk" recently in $7^{\text {th }}$ April on occasion of World Health Day 2017. ${ }^{[14]}$

\section{Mortality associated with depression}

Depression and suicide are closely interlinked; at its worst, depression can lead to suicide. Globally, an estimated 322 millio. people were affected by depression 2015.India is home to an estimated 57 million people (18\% of the global estimate) affected by depression. ${ }^{[15]}$ People with depression are 1.52 times more likely to die than the general population, probably due to their untreated mental or physical health problems. ${ }^{[16]}$ Further, with depression being associated with many terminal illnesses, the contribution to mortality could be much higher.

In addition, the association of depression and suicides are well established and studies have shown the probability of deaths from suicide among depressed patients to be $15 \% .{ }^{[17]}$ Certain vulnerable situations and particular risk groups are also at an increased risk, as in the case of farmer suicides. Psychological autopsy studies reported a depression prevalence ranging from $2 \%$ to $37.7 \%$ among suicide decedents. ${ }^{[18-21]}$ Depression is an extremely common illness affecting people of all ages, genders, different socioeconomic groups and religions in India and all over the world

\section{Multiple risk factors of Depression}

Depression is due to multiple factors resulting from complex mechanisms; there can be no single identifiable cause. However, there is conclusive evidence to reveal that several biological, social, economic, cultural and environmental factors operate in a mal adjusted individual, leading to depression. One may develop depression due to the loss of a loved one, or it may unfold in the backdrop of multiple social or financial stresses, or on an account of a family history of depression, or it may begin in the background of a chronic medical condition. Some individuals can experience loneliness and feeling low for no apparent reason at all. It is crucial to note that recognition of these factors is important to provide appropriate intervention for the affected individual and to support the family.

\section{Biological factors}

About a third of depression cases are linked to genetic factors and the rest to nongenetic or environmental factors. ${ }^{[22]}$ However, vidence of the role of specific genes or pecific gene environment associations is not yet established. A substantial association between genetic vulnerability to depression and early childhood traumatic experiences is known to exist. Deficiency of monoamines, particularly noradrenalin and serotonin, are also known to play a role in the pathogenesis of depression.

\section{Psychological factors}

Exposure to negative parental influences such as a critical and condemning parental style during early childhood may give rise to negative feelings about oneself. The long-term consequences of separation or early loss of the maternal attachment bond are leading into depression.

\section{Social factors}

Distressing social relationships such as familial, marital and parental relationships have been associated with the onset of depression. ${ }^{[23]}$ Domestic and intimate partner violence among women, which is prevalent in India along with partner's alcohol use are closely associated with depression ${ }^{[24,25]}$. Of 
recent importance is the impact of modernization, urbanization, migration, globalization and consequent loss of family, social support systems, leading to social isolation. Cities with dense population, high migration, poor planning or organization of services lead to health hazards and residents may be at risk for mental health problems, including depression. ${ }^{[26]}$

\section{Cultural factors}

Culture plays a significant role, such as religion, caste, beliefs, attitudes, interpretations and symptom thresholds, which vary across different parts of India. People with depression often have features related to various socio-cultural contexts.

\section{Economic factors}

People who experienced acute (sudden economic crisis) or chronic (poor income households) economic adversities are more vulnerable to developing depression. Individuals living in conflict zones or at times of natural disasters are also likely experience depression to a greater extent.

\section{Depression according to Ayurveda}

In Ayurveda classics, mental health has a great importance for all over healthy personality. According to Sushruta, man is said to be Swastha (Healthy) whose doshash(bio-energies)agnis(digestive

activity), dhatus(basic tissues), and malas(waste products) are in the state of equilibrium along with pleasent state of soul, sense organs and mind. ${ }^{[27]}$ The three basic qualities of mind consists of sattva (intelligence/quiteness), rajas (activity/turbulence), tamas (inertia/darkness).Out of which rajas and tamas vitiates leads to different manasika vikaras (mental disorders) like Vishad (Depression), dainya (misery), udvega (anxiety), bhaya (fear), shanka (uncertainity), irshya (jealousy) etc. ${ }^{[28,29,30]}$ Persons with high rajas and tamas qualities are more prone to develop mental disturbances. This leads to recollection of negative thoughts, fearful memories, false perception, wrong analysis, irrelevant thinking, wrong decision, in that person. This sequence of events repeats and may result into depression or any type mental illness. Depression is also responsible for to increase the severity of other diseases. ${ }^{\text {[31] }}$

Acharya Charaka quoted that, perverted, negative and excessive use of prajnaparadh (intelligence), asatmendriyarth sanyog (sense objects), and parinam (time) collectively disturb the homeostasis causing different types of physical as well as mental disorders, and depression is being one among them. ${ }^{[32,33]}$. Also not achieving things desired for, or getting undesired things leads to mental disorders. $^{[34]}$

\section{Management of depression in Ayurveda}

Depression is purely a mental disorder, having its effect on whole body. In Ayurveda treatment of depression is done on the line of manas vikaras. Management of manas vikaras in Ayurveda is as below.

Nidana parivarjana Chikitsa (Avoidance of ausative factor) -The first step of treatment fisease involves removal of cause or nidan parivarjan. ${ }^{[35]}$ and acceptance of knowledge, restraint, memory and mediation. ${ }^{[36]}$ The most important is to avoid prajnaparadh (intellectual errors).Controlling sense organs, keeping intact memory, proper knowledge of time, place and one self. ${ }^{[37]}$

\section{Sattvavajaya (psychological or spiritual} therapy) -means controlling the mind with right thinking (Vichara). Sound and positive mental health can only be maintained with right kind of thinking. A person who is mentally fit and healthy has self- satisfaction, accommodative intellect, ability to accept criticism, understanding of the emotional needs of others, and self-control. Such individuals are neither driven by greed or lust nor dominated by fear, anger, attachment, jealousy, guilt or worry. It consists of developing the clear or sattvic quality of the mind for gaining self-knowledge and thereby freedom from desire. The best approach to achieve the goal of sattvavajaya chikitsa is through jnanam (knowledge), vijnanam 
(analytical thinking), dhairya, (courage), smrti (memory), and Samadhi (concentration), according to sage Caraka. ${ }^{[36]}$ Psychological therapy is restraint of mind from the unwholesome objects. ${ }^{[34]}$

\section{Daivavyapashraya (divine or religious}

therapy) - is applied to those diseases which are neither purely physical nor psychological. It consists of various subtle, religious, or occult methods to ward off negative influences and to promote those which are good. It includes chanting mantras, the spiritual use of herbs and gems, rituals for giving good fortune ( mangala ), offerings of oblations ( bali ), offerings in general ( upahara), fasting ( upavasa), pilgrimages ( gamana), performance of prostrations ( pranipata), fire sacrifices ( homa ), ceremonial penances ( prayaschitta), practise of healthy religious rituals (niyama), and rituals for well-being. ${ }^{[34]}$

Yuktivyapashraya (rational or objectively planned therapy)- means use of scientific medicines, vihara (right recreation) with ahar (dietary regimen). ${ }^{[34]}$ In right recreation Nasy (nasal instillation), abhyanga, samvahan(massage), and tailadhara (streaming of medicated oil/decoction on the forehead of the person) plays an important role to remove stress and relax the body and have soothing effect on mind. Abhyang removes fatigue and numbness 24 and daily regular massage on the head, face and neck to relieve your own stress and anxiety, and lift your mood from depression, ${ }^{[38]}$ while Samvahan provides pleasure sleep and is aphrodisiac. ${ }^{[39]}$ In today's hectic and stressful day of everyone, a good and sound sleep is must. It provides development, complexion, strength, and enthusiasm. ${ }^{[40]}$ In Ayurveda, food is considered to be an important medicine for both mind and body. Food not only nourishes the body but also has a close relation with mind. In order to reduce stress, one should try to choose foods that increase "sattva". Natural, fresh and vegetarian food items increase "sattva". Fresh fruits, fruit juices, vegetables (raw or cooked or boiled), vegetable juices, sprouts, nuts, dry fruits, honey, milk, ghee, fresh butter, and buttermilk are the best to increase sattva. Avoid deep fried foods ,hot spices, meat, fish, and eggs ,these items increase rajas and tamas qualities of mind. ${ }^{[41]}$

Naisthiki Chikitsa( liberation therapy) - the supreme treatment is that which is devoid of upadha (desire/allurement) is known as Naisthiki Chikitsa. Desire is the root cause of all miseries. Sacrifice of all desire is the factor to vanish all miseries. ${ }^{[42]}$ Love, hatred all called as attachment, they are the root cause of miseries and detachment from the six enemies i.e. kama (desire), krodha (anger), lobha (greed), moha (attachment),mada(ego),matsar(jelousy) is ultimate bliss. ${ }^{[43]}$

Importance of Sadvritta (codes of conduct ) and Achara Rasayana- Association with good people leads to development of good behavior, which considered as sadvritta. Sadvritta and achara rasayana not only includes mental Aculties, but also rules related with general ygiene, religion, food consumption, sexual intercourse and exercise, following which leads to prevention of psychological, physical, and psychosomatic disorders, ultimately preventing suicidal attempts in current scenario. ${ }^{[44,45]}$

Medhya Rasayanas (Mental tonics)- medhya rasayana is a group of herbs that promotes intelligence, understanding, increase memory, strengthen the power of mind and maintain the equilibrium of mental health. It consists of Brahmi, Jatamamsi, Shankhpushpi, Guduchi,Cyavanaprasa rasayana etc. ${ }^{[46]}$

Apart from these, measures like calming the patient with assurances and words of eligious and moral import,

\section{Management of depression as per yoga-}

Yoga is a system of physical and mental self improvement and final liberation that people have been using for thousands of years. Yoga arose in the age of the Vedas and Upanishads. It is India's oldest scientific, 
perfect mental and spiritual discipline. Yoga can serve both the individual and society. It is neither a sect nor an ideology but a practical training of mind and body. Yoga teaches us truth through mind and body rather than theory; it brings about deep change of attitude. On mental level it proves to be an applied method to train the mind to concentrate; it offers way to treat serious psychosomatic illness without drugs; it is an efficient tool for ending depression, anxiety, addictions and other bad habits with preventing suicidal attempts. Within the Yoga Sutras of Patanjali, the sage enumerates several interlocking methods to achieve the mental stability. Yoga means union, the joining of body, mind and spirit with the soul of the universe.

\section{Yogash chitta virtti nirodhah.}

These are perhaps the most important words of the entire Yoga Sutra. Here the Master tells us meaning of yoga, which is learning to stop the great mistake. And what is The Great Mistake? Our mind turns; meaning it turns things around the wrong way. Yoga restraining the mind-stuff (Chitta) from takin various forms (Vrtti).It is the suppression of the transformation of the thinking principle. ${ }^{[47]}$

\section{Management of depression through ashtang} yoga-

As per yoga sutras of Patanjali, yama (ethical rules),niyama(principles for personal/ social well being), asan (yoga posture), pranayama (breathing techniques), pratyahara (control of sense organs), dharana (continued attention to object), dhyan (mediatation), and samadhi (super-consciousness) are stages of the gradual withdrawal of consciousness from outward contact and a simultaneous rising into wider and wider dimensions of itself, culminating in infinitude which is its quintessential essence. ${ }^{[48]}$ Yama and niyam are ethical practices provide the power and courage needed to face all obstacles. Ahimsa (non violence), satya (truth), asteya (non stealing), brahmacharya (celibacy), and aparigraha (not desiring for other's things) are five yama. While niyama consists of Saucha (purity internally and externally), santosh(satisfaction), tapas (penance), svadhyaya(sacred study), and ishvarapranidhana(surrender of oneself to God). Yama and niyama teaches, how to satisfy with achievements and prevent the loss caused by over expectations, ultimately decrease the desire, stress and depression consequently.

Asana and pranayama are intended for establishing peace and harmonious relations with the muscles, nerves and the vital force. The asana should be firm and easy. It should be steady and not cause discomfort of any kind. It should be a normal posture in which person can sit for a long time. The Asana should be effortless. There should be no effort not only in the body but also in the mind. Absolute ease of relaxation is the sign of perfected asana, when one is supposed to have mastered asana (asana-Jaya). The body is the vehicle of the nerves, the nerves are the channels of the prana, the prana is an expression of the mind, and the mind it is which practices meditation, in the end. There this long linkage, and so the moment of armonious posture is assumed, the mind receives intimation thereof. The body is at once calmed down in its metabolic process, and hunger and thirst are lessened. Even emotions can be subdued by Asana, for here one inhales and exhales calmly, and so the cellular activity of the body comes down, the nerve-channels are opened up for a rhythmic flow of the prana, and a rhythm sets in everywhere.

Asanas and pranayama relaxes the mind and tone up the nervous system, endocrine system and the activity of internal organs. By practicing these, one can develop mental equilibrium, balance, endurance, and great vitality. The deep relaxation during Savasana() provides relief from any kind of physical and mental stress in few minutes and has regenerative effect on the mind and the body.

Pranayama breathing help to relax shattered brain cells and stressed out nerves by calming the various electrical activity going on in the stressed anxious brain, shutting down 
unwanted activity, and regulating the normal flow of impulses in the neurons in the brain. In depression the production of our own endorphins are reduced and these are increased by doing exercise, yoga, Pranayama breathing. That is why modern medicine now recommends exercise as essential tool to lift depression, reduce anxiety and stress, as well as maintaining healthy heart and circulation. Pranayama enhances one's ability to hold on to thoughts by reducing the number of breaths per minute. This brings calmness to the mind. During Bhramari pranayama sound is produced like the large black bee, which vibrate cerebral cortex, and send impulse to the sympathetic and parasympathetic nervous systems (PNS). PNS is associated with a relaxed and calm state of mind and body. Under the relaxing effects of PNS, autonomic nervous system facilitates to decrease the stressing effects of sympathetic nervous system and channels it towards more relaxed PNS..

Pratyahara is the withdrawal of th powers of the senses from their respectiv objects. Pratyahara means 'abstraction' 'bringing back'. It should also go side by side with Vichara or a careful investigation of every psychological condition, due to this the sense organs are under the complete control of mind. Pratyahara establishes peace with the mind and changes thinking of person from suicidal attempts to pleasure.

Dharana, Dhyana, and Samadhi these are meditative practices and acts as a powerful mental as well as nerve tonic. Considerable changes take place in the mind, brain and the nervous system by the practice of meditation. The whole mind and nervous system are remodeled. Person will develop a new view of mind, new sensations, new feeling,new mode of thinking, acting and a view of the universe. Meditation with and without Om (AUM) chanting is now unequivocally accepted as effective in helping us stabilize our mind and emotions, widely practiced and accepted not only as a self- help therapy in stress, anxiety and depression but also in daily life.

\section{DISCUSSION:}

After reviewing the literature, we can see that the incidence rate of suicide and suicidal attempts increased globally. Suicide prevention is a global mental health priority worldwide. So to prevent this incidence, WHO launches the theme 'Depression Let's Talk' recently in April 2017. Multiple factors are responsible for this phenomenon. In India suicidal attempts in farmers due to climate variability and in youth due to playing a "Blue Whale Challenge"- "cyber suicide" is a further cause for concern. Today's fast and unstable life style has given money but has taken a large burden on physical and mental health of human leading to stress, depression and mental disorders. There is a close and scientifically proved relation between suicide and lepression.

In Ayurvedic classics importance of mental aspect in maintaining overall health is clearly established. Mental element is one of the basic concepts of Ayurveda. Various causes, features and treatments both medicinal and non-medicinal have been discussed in Samhitas. In support of its concepts on preservation and promotion of health and prevention of illnesses, Ayurveda lays due stress on various measures to be adopted in order to promote mental health and prevention of health ultimately prevent mental disorders. These measures find lucid descriptions in the chapters devoted to dinacarya (daily regimen) rutucharya (seasonal regimen), sadvritta (code of virtues), roganutpadana (prevention of diseases) and anna-pana-vidhi (rules pertaining to food and drinks).

In order to be free from mental disorders Ayurveda prescribes that one should not allow oneself to become a victim of impulses like greed, grief, fear, anger, jealousy, impudence, vanity etc. Further, it 
declares that, one who speaks truth, refrains from over indulgence in alcohol and meat, hurts none, avoids overstrain, fair spoken, always compassionate and given to wholesome eating, would enjoy the benefits of sound mental health

The role of yoga especially Savasana, Om $(A U M)$ chanting, meditative practices and Pranayama i.e. Bhramari Pranayama worth to be noted.These mode of action clearly describes its effectiveness in mental disorder of any type. Yoga is the method by which the restless mind is calmed and the energy directed into constructive channels. It is observed that yoga improves attention and emotional control as well as affects the nervous system, making the parasympathetic nervous system more dominant and stabilizing the autonomic nervous system to enhance resistance to the effect of stress.Yoga practices including asan's, slow breathing, meditation, increases activation of P.N.S. and leads to mental relaxation.

The time honored system of Ashtang Yoga is a very useful technique to stabilize ou mind and emotions through the various selfdiscipline exercises, postures, studying the spiritual science and mindful meditation is a comprehensive self -help tool to maintain peace, tranquility, and self-confidence. Yoga is science of life, it offers us simple, easy remedies and techniques and methods of health and hygiene to assure physical and mental fitness with a minimum of time, effort and expense.

\section{CONCLUSION:}

Suicide and suicide attempts are a significant public health issue throughout the world and a major source of morbidity, mortality and health care cost. Suicidal behavior occurs on a continuum from thoughts and ideas to attempts and death. With timely and effective evidence-based interventions, treatment and support, both suicides and suicide attempts can be prevented by adopting the principles of Ayurveda and Yoga.
Ayurveda and Yoga classics have described a set of rules for nearly everything needed in life. That's why they are known as "science of life" nor a basically a source of medicine. Following them it is possible to lead a healthy life, depression like mood disorder can be tackled and kicked off life.. Physical fitness is basic attempt to get the mental fitness and so both cannot be neglected and have mutual importance. Ayurveda has two main aims preventive and curative. Principles of sadvritta, aachararasaayan, dincharya, rutucharya aims at prevention of stressful conditions. Measures to increase quality of life and to prevent individual from any kind of stress should be adopted to prevent suicides. Detailed regimen to increase the quality of life and to manage the stress with the help of Ayurveda and yoga including sattavajay and devavyapshray chikitsa along with yogasanas, dhyan, yam, niyam and pranayama provides a new cost effective, harmless and acceptable solution to prevent and manage depression, the pot cause of suicides.

\section{REFERENCES:}

1) http://www.who.int/mental health/preven tion/suicide/suicideprevent/en/(Accessed date 21.6.2017).

2) http://www.who.int/mental_health/preven tion/suicide/suicideprevent/en/(Accessed date 21.6.2017).

3) http://www.who.int/mental_health/preven tion/suicide/suicideprevent/en/(Accessed date 21.8.2017).

4) http://www.who.int/mediacentre/factsheet s/fs398/en/( Accessed date 21.08.2017)

5) Global Health Estimates 2015: Deaths by cause, age, sex, by country and by region, 2000

2015.Geneva:WHO;2016(http://www.wh o.int/healthinfo/global_burden_disease/est imates/en/index 1.html),WHO Member States with a population of less than 90 000 in 2015 were not included in this analysis. 
6) Global Health Estimates 2015:Deaths by cause, age, sex, by country and by region, 2000-

2015.Geneva:WHO;2016(http://www.wh o.int/healthinfo/global_burden_disease/est imates/en/index1.html),WHO Member States with a population of less than 90 000 in 2015 were not included in this analysis.

7) https://thewire.in/wpcontent/uploads/2017/04/Annex-1$\%$ E2\%80\%93-Farmer-suicides-2016-and2017.pdf(Accessed date 21.8.2017).

8) J Hardikar, Farmer suicides:Maharashtra continues to be worst affected $10^{\text {th }}$ year in row

(htpp://www.dnaindia.com/Mumbai/repor t-farmer-suicide Maharashtra continues to be worst affected $10^{\text {th }}$ year in row)

9) Blue Whale: Should you be worried about online pressure groups?" (http://www.bbc.com/news/world39729819).

10) Teen Suicide Games Send Shudder Through

Russian

SpeakingWorld"(https://www.rferl.org/a/r ussiateen-suicide-blue-whale-internet social media game/28322884.html.

11) Rajagopal S. Suicide pacts and the internet. BMJ 2004;329:1298-9.

12) Birbal R, Maharajh HD, Clapperton M, Jarvis J, Ragoonath A, Uppalapati K. Cybersuicide and the adolescent population: Challenges of the future? Int J Adolesc Med Health 2009;21:151-9.

13) Saxena S, Krug EG, Chestnov O, World Health Organization, editors. Preventing suicide: a global imperative. Geneva: World Health Organization; 2014.

14) www.who.int/world-healthday/(Accessed date 15.4.2017)

15) Depression and other common mental disorders: global health estimates. Geneva:

World Health Organization; 2017 (http://apps.who.int/iris/handle/10665/254 610 ,)
16) Cuijpers $P$, Vogelzangs $N$, Twisk $J$, Kleiboer A, Li J, Penninx BW. Comprehensive Meta- Analysis of Excess Mortality in Depression in the General Community Versus Patients With Specific Illnesses. Am J Psychiatry. 2014;171:453-62.

17) Simon GE, VonKorff M. Suicide mortality among patients treated for depression in an insured population. Am J Epidemiol. 1998;147:155-160.

18) Bhise MC, Behere PB. Risk factors for farmers' suicides in central rural India: Matched case-control psychological autopsy study. Indian J Psychol Med. 2016;38:560.

19) Manoranjitham SD, Rajkumar AP, Thangadurai P, Prasad J, Jayakaran R, Jacob KS. Risk factors for suicide in rural south India. $\mathrm{Br} \mathrm{J}$ Psychiatry. 2010;196:26-30.34

20) Chavan BS, Singh GP, Kaur J, Kochar R. Psychological autopsy of 101 suicide cases from northwest region of India. Indian J Psychiatry. 2008;50:34-8.

21) Vijayakumar L, Rajkumar S. Are risk factors for suicide universal? A casecontrol study in India. Acta Psychiatr Scand. 1999;99:407-11.

22) Sullivan PF, Neale MC, Kendler KS. Genetic epidemiology of major depression: review and meta-analysis. Am J Psychiatry. 2000;157:1552-62.

23) Bauwens F, Pardoen D, Staner L, Dramaix M, Mendlewicz J. Social adjustment and the course of affective illness: a one-year controlled longitudinal study involving bipolar and unipolar outpatients. Depress Anxiety. 1998;8:507.

24) Varma D, Chandra PS, Thomas T, Carey MP. Intimate Partner Violence and Sexual Coercion among Pregnant Women in India: Relationship with Depression and Post Traumatic Stress Disorder. J Affect Disord. 2007;102:227-35. 
25) Haqqi S, Faizi A, Haqqi S. Prevalence of Domestic Violence and associated Depression in married women at a Tertiary care hospital in Karachi. Procedia - Soc Behav Sci. 2010;5:1090-7.

26) Chen J, Chen S, Landry PF. Urbanization and Mental Health in China: Linking the 2010 Population Census with a CrossSectional Survey. Int J Environ Res Public Health. 2015;12:9012-24.

27) Athavale $P$ G.Drushtarth Sushruta Chintan.Vol.1(Sutrasthana).

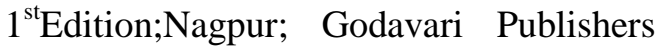
and Book Promoters; 2008. p.145.

28) Dwivedi Laxmidhar,Dwivedi B K,Goswami P K.Charak Samhita.

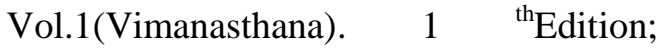
Varanasi; Chaukhambha Krishnadas Academy; 2007.p.840.

29) Dwivedi Laxmidhar,Dwivedi B K,Goswami P K.Charak Samhita. Vol.1(Vimanasthana). $\quad 1^{\text {th }}$ Edition; Varanasi; Chaukhambha Krishnadas Academy; 2007.p.802.

30) Dwivedi Laxmidhar,Dwivedi

K,Goswami P K.Charak Samhita Vol.1(Nidanasthana). $1^{\text {th }}$ Edition; Varanasi; Chaukhambha Krishnadas Academy; 2007.p.735.

31) Dwivedi Laxmidhar,Dwivedi B K,Goswami P K.Charak Samhita. Vol.1(Sutrasthana). $1^{\text {th }}$ Edition; Varanasi; Chaukhambha Krishnadas Academy; 2007.p.449.

32) Dwivedi Laxmidhar, Dwivedi B K, Goswami P K.Charak Samhita. Vol.1 (Sutrasthana). $\quad 1^{\text {th }}$ Edition; Varanasi; Chaukhambha Krishnadas Academy; 2007.p.45.

33) Dwivedi Laxmidhar, Dwivedi B K,Goswami P K.Charak Samhita. Vol.1 (Sutrasthana) $\quad 1^{\text {th }}$ Edition; Varanasi; Chaukhambha Krishnadas Academy; 2007. p. 192.

34) Dwivedi Laxmidhar,Dwivedi B K,Goswami P K.Charak Samhita. Vol.1(Sutrasthana). $1^{\text {th }}$ Edition; Varanasi;
Chaukhambha Krishnadas Academy; 2007.p.273.

35) Athavale $P$ G.Drushtarth Sushruta Chintan.Vol.- 2(Uttartantra). $1^{\text {st Edition; }}$ Nagpur; Godavari Publishers and Book Promoters; 2008.p.350.

36) Dwivedi Laxmidhar,Dwivedi B K,Goswami P K.Charak Samhita. Vol.1 (Sutrasthana). $\quad 1^{\text {th }}$ Edition;Varanasi; Chaukhambha Krishnadas Academy; 2007.p.54.

37) Dwivedi Laxmidhar,Dwivedi B K,Goswami P K.Charak Samhita. Vol.1 (Sutrasthana). $\quad 1^{\text {th }}$ Edition; Varanasi; Chaukhambha Krishnadas Academy; 2007.p.193.

38) Tripathi Brahmanand, Ashtang Hridyam. (Sutrasthana). Reprint; Delhi; Chaukhamba Sanskrit Pratishthan; 2012. p.29.

39) Athavale P G.Drushtarth Sushruta Chintan.Vol.-2(Chikitsasthana). $1{ }^{\text {st }}$ Edition; Nagpur; Godavari Publishers and Book Promoters; 2008.p.168.

40) Dwivedi Laxmidhar,Dwivedi B K,Goswami P K.Charak Samhita. Vol.1(Sutrasthana). $\quad 1^{\text {th }}$ Edition; Varanasi; Chaukhambha Krishnadas Academy;2007.p.407.

41) A C Bhaktivedant Swami Prabhupad, Bhagavad-gita As It Is, 20 $0^{\text {th }}$ Edition; Mumbai; Bhaktivedant Book Trust; 2010.p.552-553.

42) Dwivedi Laxmidhar, Dwivedi B K, Goswami P K.Charak Samhita. Vol.2 (Sharirasthana). $\quad 1^{\text {th }}$ Edition; Varanasi; Chaukhambha Krishnadas Academy; 2007.p.985.

43) Yadavaji Trikamji Acharya. Charak Samhita Commentary, (Sharirasthana). Reprint; Varanasi; Chaukhambha Sanskrit Sansthan; 1984.p.326.

44) Dwivedi Laxmidhar,Dwivedi B K,Goswami P K.Charak Samhita. Vol.1(Sutrasthana). $\quad 1^{\text {th }}$ Edition;Varanasi; Chaukhambha Krishnadas Academy; 2007.p.207-216. 
45) Harish Chandra Singh Kushwaha, Charak Samhita. Vol.2 (Chikitsasthana). $1^{\text {th }}$ Edition; Varanasi; Chaukhambha Orientalia; 2009.p.43.

46) Harish Chandra Singh Kushwaha, Charak Samhita. Vol.2 (Chikitsasthana). $1^{\text {th }}$ Edition; Varanasi; Chaukhambha Orientalia; 2009.p.30.

47) Dr. Vedvrata Alok, Patanjal Yoga Shastra Sutra- vivaranam, $2^{\text {nd }}$ Edition;
New Delhi; Kendriya Yoga evam Prakrutik Chikitsa Anusandhan parishad, AYUSH Dept.2007.p.29.

48) Dr.Vedvrata Alok, Patanjal Yoga Shastra Sutra- vivaranam, $2^{\text {nd }}$ Edition; New Delhi; Kendriya Yoga evam Prakrutik Chikitsa Anusandhan parishad, AYUSH Dept.2007.p.279.

\section{Cite this article:}

Prevention of suicidal attempts in present era through ayurveda and yoga.

Patil Rajendra Vinayak, Kathane Vikas Charandas, Patrikar Vijay Gangadhar Ayurlog: National Journal of Research in Ayurved Science-2018; 6(2): 1-11 